\title{
Regulation of Endothelial Permeability in the Corpus Luteum: A Review of the Literature
}

\section{Regulation endothelialer Permeabilität im Corpus luteum: eine Literaturübersicht}

Authors

Affiliations

\author{
D. Herr ${ }^{1}$, I. Bekes ${ }^{2}$, C. Wulff ${ }^{2}$
}

${ }^{1}$ Frauenklinik, Universitätsklinikum Homburg/Saar, Homburg

${ }^{2}$ Frauenklinik, Universitätsklinikum Ulm, Ulm
Key words

- permeability

- tight junction

- adherens junction

- corpus luteum

- hCG

Schlüsselwörter

- Permeabilität

- Tight Junction

- Adherens Junction

- Corpus luteum

- hCG

Deutschsprachige Zusatzinformationen online abrufbar unter: www.thieme-connect.de/ ejournals/toc/gebfra

$\begin{array}{ll}\text { received } & 14.7 .2013 \\ \text { revised } & 17.9 .2013 \\ \text { accepted } & 19.9 .2013\end{array}$

Bibliography DOI http://dx.doi.org/ 10.1055/s-0033-1351032 Geburtsh Frauenheilk 2013; 73 : 1107-1111 @ Georg Thieme Verlag KG Stuttgart · New York . ISSN 0016-5751

\section{Correspondence}

\section{PD Dr. Daniel Herr}

Universitätsklinikum

Homburg/Saar

Frauenklinik

Kirrbergerstraße 100

66424 Homburg

daherr@gmx.de

\section{Abstract \\ $\nabla$}

The development of the human corpus luteum (yellow body) is dictated by a strictly controlled system of mutually communicating cells, the luteal steroid hormone-producing cells and endothelial cells. This cell-to-cell communication facilitates control of neoangiogenesis which is a prerequisite for the development of the corpus luteum and its function, the rapid release of large amounts of progesterone into the blood-vascular system. Preconditions for this process are the hormonal regulation of endothelial cell proliferation as well as of vascular permeability through $\mathrm{LH}$ and hCG. The morphological correlates of endothelial permeability are cell-to-cell adhesion molecules such as adherens junctions (AJ) and tight junctions (TJ) that open and close the gaps between mutually interacting, neighbouring endothelial cells like a "zip fastener". Various types of cell adhesion molecules have been detected in the corpus luteum such as occludin, claudin 1 and claudin 5 as well as VE-cadherin. It may be assumed that the regulation of $\mathrm{AJ}$ and TJ proteins is of particular importance for the permeability and thus for the function of the corpus luteum in early pregnancy since hCG treatment leads to a downregulation of cell adhesion molecules in the luteal vessels. This effect is apparently mediated by VEGF. From a functional point of view, the hCGdependent and VEGF-mediated down-regulation of cell adhesion molecules leads to a reduced transmissibility of cell-to-cell contacts and thus to an increased endothelial permeability. In this process the various cell adhesion molecules are not only directly regulated by VEGF but they also mutually interact and thus influence one another.

\section{Zusammenfassung \\ $\nabla$}

Die Entwicklung des humanen Corpus luteum ist durch ein streng reguliertes System von miteinander kommunizierenden Zellen, den lutealen Steroidhormon-produzierenden Zellen und den Endothelzellen, geprägt. Diese Zell-Zell-Kommunikation ermöglicht die Kontrolle von Neoangiogenese, die für die Entstehung des Corpus luteum Voraussetzung ist, und deren Aufgabe die rasche Freigabe von großen Mengen Progesteron ins Blutgefäßsystem ist. Voraussetzung für diesen Vorgang ist die hormonelle Regulation der Endothelzellproliferation sowie der Gefäßpermeabilität durch LH und hCG. Das morphologische Korrelat der endothelialen Permeabilität sind Zell-ZellAdhäsionsmoleküle wie Adherens Junctions (AJ) und Tight Junctions (TJ), die „reißverschlussartig“ den Spalt benachbarter interagierender Endothelzellen öffnen und schließen. Im Corpus luteum konnten verschiedene Zell-Adhäsionsmoleküle nachgewiesen werden, darunter Occludin, Claudin 1 und Claudin 5 sowie VE-Cadherin. Es ist davon auszugehen, dass die Regulation von AJ- und TJ-Proteinen von besonderer Bedeutung für die Permeabilität und damit die Funktionalität des Corpus luteum in der Frühschwangerschaft ist, da hCG-Behandlung zu einer Herunterregulation der Zell-Adhäsionsmoleküle in den Lutealgefäßen führt. Offensichtlich ist dieser Effekt VEGF-vermittelt. Funktionell betrachtet führt die hCG-abhängige und VEGF-vermittelte Herunterregulation von Zelladhäsionsmolekülen zu einer verminderten Durchlässigkeit der Zell-Zell-Kontakte und damit zu gesteigerter endothelialer Permeabilität. Dabei werden die verschiedenen Zell-Adhäsionsmoleküle nicht nur direkt durch VEGF reguliert, sondern sie interagieren auch untereinander und beeinflussen sich auf diese Weise gegenseitig. 


\section{Introduction}

The corpus luteum (yellow body) is an intermediary, endocrineactive gland that alternately undergoes generation and degeneration in the course of the cycle. Hereby the corpus luteum plays a central role in maintaining pregnancy. The pre-ovulatory LH peak at first triggers ovulation and then induces the very rapid transformation of the ruptured follicle into a corpus luteum. This process proceeds mainly under the control of progesterone that is synthesised by the corpus luteum and is essential for implantation and the maintenance of pregnancy [1]. If a pregnancy does not occur, the corpus luteum degenerates 14 days after ovulation into a corpus albicans with transformed connective tissue. However, if the egg cell is fertilised the persistence of the corpus luteum is ensured both directly and indirectly by the joint effects of LH and hCG [2-7]. This observation is supported by the fact that the corpus luteum can be maintained in the absence of a pregnancy by exogenous administration of hCG [8].

The corpus luteum consists of various types of cells including endothelial cells, luteinised granulosa cells and luteinised theca cells. The endothelial cells are responsible for controlling vascular permeability which represents an indispensable prerequisite for the development of the corpus luteum. The permeability itself is controlled by the strictly regulated opening and closing of the cell-to-cell contacts between the endothelial cells [9-11]. For these reasons, any impairment of the expression of AJ and TJ can lead to a perturbed endothelial cell function with consecutive functional consequences such as, e.g., oedemas or ascites within the framework of an ovarian hyper-stimulation syndrome (OHSS) [12-14]. In such cases, the iatrogenous administration of hCG to support the luteal phase is effective; this increases luteal function but also increases the risk for the occurrence of OHSS [15]. Such a syndrome is characterised by an increased permeability of the capillaries which leads to a fluid shift from intravasal to extravasal spaces and thus to ascites [16]. In the following paragraphs the exact molecular mechanisms that participate in the regulation of endothelial function and thus the fluid barriers of the vessels are described. A better understanding of these mechanisms will hopefully aid the development of novel therapeutic options in the future and thus the ability to limit tissue damage by influencing vascular permeability.

\section{Molecular Regulation of Endothelial Permeability \\ $\nabla$}

The paracellular endothelial permeability is controlled by at least two different types of cell-to-cell contacts, the AJ and the TJ. These are formed from various transmembrane proteins that promote homophilic cell-to-cell contacts and transmit intracellular signals [17]. It has been shown several times that these cellto-cell contacts are dynamically transformed not only during embryonic development but also in resting cells [18]. Adhesion molecules such as AJ and TJ thereby form complexes that regulate the permeability in a zipper-like manner, i.e., the transmissibility of the gaps between neighbouring, mutually interacting cells [1922].

Endothelial cells express tissue-specific transmembrane proteins: the AJ protein VE (vascular endothelial) cadherin and the TJ protein claudin 5 [9,23]. Claudin 5-deficient knockout mice show a normal embryonic development but die shortly after birth due to a defect of the blood-brain barrier [23]. In comparison, VE-cadherin-deficient mice suffer from numerous severe le-

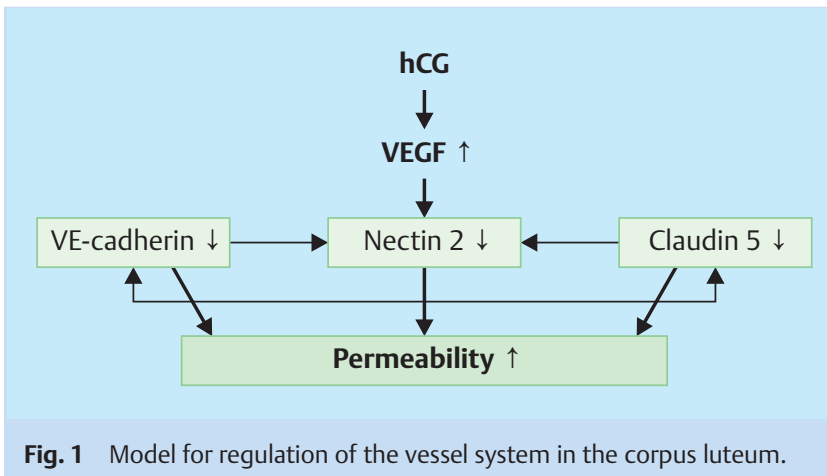

thal defects in the course of embryonic angiogenesis [24]. This indicates that adhesion molecules not only have a structural but also a major functional relevance.

\section{Distribution of Cell Adhesion Proteins in the Human Corpus Luteum}

$\nabla$

Widely differing cell adhesion molecules can be localised in the corpus luteum. These include the TJ proteins occludin, claudin 1 and claudin 5 as well as the AJ protein VE-cadherin. The distribution of these cell-to-cell contacts naturally differs in the various compartments of the corpus luteum. In the human corpus luteum occludin can be detected ubiquitously in the membranes of endothelial cells in the vicinity of granulosa and theca capillaries as well as in the membranes of luteinising granulosa cells themselves. In contrast, however, occludin is not expressed in the domain of luteinising theca cells [25]. The detection of occludin in epithelial and endothelial cells has also been described for other types of tissue such as, e.g., rat lung, human liver, mouse brain, etc. [26-30].

Claudin 1 is exclusively expressed in the domain of the membrane of luteinising granulosa cells. In contrast to occluding, claudin 1 can only be discontinuously detected and not band-like. This distribution pattern is comparable with that which can be observed on the surface of human ovarian epithelium [31]. In contrast to the endothelial cells of the brain and salivary glands, claudin 1 is not expressed in the domain of luteal vessels [32,33]. Claudin 5, on the other hand, is exclusively and specifically localised in the endothelium of the human corpus luteum. Thereby it can be detected above all in the capillaries of the granulosa compartment and in the larger vessels of the theca [25]. VE-cadherin, on the other hand, can be detected not only in capillary endothelium of the granulosa but also in that of the theca. There is no unambiguous explanation for the so widely differing tissue-specific occurrence of these proteins, but it is apparent that in certain cell compartments a combination of various $\mathrm{AJ}$ and $\mathrm{TJ}$ is responsible for the mediation of cell-to-cell communication and adhesion [25].

\section{Functional Relevance of hCG with Respect to Cell Adhesion Proteins in the Human Corpus Luteum $\nabla$}

The cyclic growth and development of the corpus luteum is regulated by gonadotropins. During the normal cycle its life span is limited to 14 days under the influence of LH. In the case of a preg- 
nancy the corpus luteum survives for several months due to the effect of hCG, this is known as "luteal rescue". It has been shown for the human corpus luteum that "luteal rescue" is accompanied by an expansion of the luteal vessels [34], which presumably involves a re-arrangement of cell adhesion proteins. Thus, it is of particular interest to examine the effects of hCG on $\mathrm{AJ}$ and $\mathrm{TJ}$ in the human corpus luteum.

In the "rescued" human corpus luteum of an in vivo pregnancy simulated by hCG, claudin 1 and occludin are significantly down-regulated in the luteinising granulosa cell compartment [25]. In addition, there is a decrease of occludin, claudin 5 and VE-cadherin in the endothelial cell compartment. It may be assumed that this hCG-dependent regulation of AJ and TJ proteins supported by the function of the corpus luteum is of exceptional importance for the maintenance of early pregnancy. The decrease in the expression of cell adhesion molecules in the luteinising granulosa cell compartment appears thereby to be a structural prerequisite for the liberation of steroidogenic molecules such as progesterone or vascular endothelial growth factor (VEGF) [35]. The development of the corpus luteum following "luteal rescue" is characterised by a structural new orientation. The downregulation of cell adhesion molecules thereby leads to an increase of the intercellular gaps which, on the one hand, favours the expansion and invasion of new vessels and, on the other hand, increases the transmissibility of the endothelium. Both facilitate the distribution or, respectively, release of hormones into the bloodstream, which are necessary for the maintenance of the early pregnancy. This is additionally supported by the fact that hCG increases the permeability of vessels $[36,37]$. In rats this increase is associated with a lowered level of claudin 5 [37].

\section{Influence of VEGF on Cell Adhesion Molecules in the Corpus Luteum of Primates}

As described above in detail, it has been shown that hCG reduces the expression of cell adhesion molecules and thus affects luteal angiogenesis and vascular permeability. In addition it has been demonstrated that the inhibition of VEGF has an inhibitory effect on ovarian angiogenesis, development and function [38-40]. Furthermore, it was shown that VEGF controls cell adhesion molecules in the marmoset monkey.

The amount of occludin localised in the domain of the membranes of luteinising granulosa cells decreases continuously in the course of the ovulation phase until it can no longer be detected [41]. This loss of occludin seems to be involved in the formation of the antrum [42,43]. In contrast, in vivo inhibition of VEGF in marmosets by a VEGF antagonist (VEGF trap) leads to a significant increase in the amount of occludin [41], above all in the cytoplasmic domains where occludin itself has no function [44].

In the marmoset the $\mathrm{TJ}$ protein claudin 5 is exclusively detected in theca vessels and its amount increases in the course of follicle maturation. In the corpus luteum, claudin 5 is also expressed in the domain of the vessels. In this case, inhibition of VEGF leads to an increase of claudin 5. Apparently, claudin 5 plays an important part in the contact inhibition of endothelial cells. In this way the rate of proliferation of the cells is reduced and the vessels stabilise themselves [41]. As soon as individual endothelial cells come into contact with neighbouring cells, the adhesion molecules combine to form complexes and the endothelium is less im- paired by the pro-angiogenic effect of VEGF. This cell adhesion is essential with regard to the regulation of angiogenesis [45].

For VE-cadherin it has been proven that this inhibition triggers a decline in the rate of angiogenesis and thus of vessel development [45]. Here VEGF acts as the key molecule for regulation of angiogenesis in the ovary $[34,35,38,39,46]$. Furthermore, a close relationship between VEGF and the signal transduction of cellular adhesion molecules has been demonstrated from functional considerations.

\section{Cell Adhesion Proteins and Permeability}

Some time ago it was demonstrated in an in vitro endothelial cell model that hCG apparently has a direct effect on the expression of VE-cadherin and on endothelial permeability [47]. However, the significance and the signal transduction of an assumed $\mathrm{LH} /$ hCG receptor are still not clear. It is proposed that the receptor exerts a hormonal transcytosis function and in this way transports gonadotropins directly to the target cell [48]. In order to study the molecular regulation of endothelial cells in the corpus luteum an in vitro co-culture model was developed. This consists of a two-chamber model of endothelial and luteinising granulosa cells in which their interactions can be studied as reactions on stimulating substances [49]. It was shown in vivo in the corpus luteum that the endothelial cell adhesion protein claudin 5 decreases after hCG treatment in the sense of a simulated pregnancy [25]; this was confirmed in the cell culture model described above. In addition, by means of hCG treatment in co-cultured luteinising granulosa cells an effect also on endothelial permeability was demonstrated for the first time [49]. Although a possible direct effect of hCG on endothelial cells cannot be excluded [47], it is apparent that the effects of hCG on claudin 5 and on permeability are of an indirect nature because they are only observed in the presence of luteinising granulosa cells. For this reason an hCG-dependent factor that is synthesised by the luteinising granulosa cells was assumed - and this factor is VEGF. The hCG treatment of luteinising granulosa cells does indeed lead to an increase of VEGF [49-51] and the action of VEGF on endothelial permeability has often been demonstrated in vitro [36, 47]. Thus, VEGF is considered to be an important paracrine factor that controls the regulation of endothelial cell permeability via an influence on adhesion proteins [52,53]. This has found support in observations in which the inhibition of VEGF in vivo suppresses not only angiogenesis but also permeability [45]. Conversely, VEGF in endothelial cells triggers the liberation of VE-cadherin and this, in turn, results in an increased endothelial permeability [49]. This fact does indeed point to a direct relationship between hCG, VEGF, cell adhesion proteins and increased permeability.

\section{Interaction of Cell Adhesion Proteins in Endothelial Cells \\ $\nabla$}

Functional interactions of cell adhesion proteins that act as regulators of vascular permeability have been demonstrated for widely differing systems. In spite of the facts that the corpus belongs by far to the most highly vascularised type of tissue and that the control of permeability is of major significance for its function, these relationships have mostly remained unknown. Cell adhesion proteins as dynamic complexes change their conformation not only during the embryonic development but also 
in resting cells of the adult vascular system [54]. They interact thereby also with one another in the sense of a response to extracellular signals $[55,56]$. Accordingly, the co-existence of widely varying cell adhesion proteins for completely different tissue types in various species has been demonstrated. For the vascular system of the human corpus luteum it has been shown that the AJ protein VE-cadherin as well as the TJ proteins nectin 2 and claudin 5 are co-localised in the middle part of the luteal phase [57]. Treatment of luteinising granulosa cells with hCG in vitro thereby leads via VEGF-mediation to a reduced expression of these proteins. Beyond this, there is a functional relationship since VE-cadherin, nectin 2 and claudin 5 mutually regulate each other. Elimination of VE-cadherin or claudin 5 triggers a down-regulation of the respective other proteins whereas nectin 2 does not have a regulatory influence on VE-cadherin and claudin 5 . These interactions are not only of a structural nature but also have a functional impact on the permeability of the endothelium. The hCGinduced down-regulation of the above-mentioned proteins leads to an increased permeability. Moreover, the separate elimination of VE cadherin, claudin 5 and nectin 2 in vitro also respectively leads to an increase in the permeability.

Taken together, this suggests that VE-cadherin and claudin 5 apparently play a significant part with regard to the regulation of permeability via nectin 2 . In addition, nectin 2 itself has a direct influence on the permeability.

Since the three proteins discussed above are co-localised in the vascular system of the corpus luteum and can be down-regulated via VEGF by treatment with hCG, it can be assumed that hCG triggers a chain reaction via VE-cadherin and/or claudin 5 , in order to control nectin 2 and concomitantly the luteal permeability (O Fig. 1) [57]. These findings may be of therapeutic relevance in situations with pathologically increased endothelial permeability such as in, e.g. OHSS.

\section{Conclusion for Clinical Practice}

\section{$\nabla$}

The occurrence of an hCG-induced increase of endothelial permeability is apparently mediated by VEGF. In cases of OHSS this mechanism may be responsible for the development of ascites and represent a possible therapeutic option in the sense of VEGF antagonism.

\section{Conflict of Interest}

$\nabla$

None.

\section{References}

1 Stocco C, Telleria C, Gibori G. The molecular control of corpus luteum formation, function, and regression. Endocr Rev 2007; 28: 117-149

2 Matsubara H, Ikuta K, Ozaki Yet al. Gonadotropins and cytokines affect luteal function through control of apoptosis in human luteinized granulosa cells. J Clin Endocrinol Metab 2000; 85: 1620-1626

3 Dickinson RE, Stewart AJ, Myers $M$ et al. Differential expression and functional characterization of luteinizing hormone receptor splice variants in human luteal cells: implications for luteolysis. Endocrinology 2009; 150: 2873-2881

4 Del Canto F, Sierralta W, Kohen P et al. Features of natural and gonadotropin-releasing hormone antagonist-induced corpus luteum regression and effects of in vivo human chorionic gonadotropin. J Clin Endocrinol Metab 2007; 92: 4436-4443

5 Duncan WC, Gay E, Maybin JA. The effect of human chorionic gonadotrophin on the expression of progesterone receptors in human luteal cells in vivo and in vitro. Reproduction 2005; 130: 83-93
6 Dickinson RE, Myers M, Duncan WC. Novel regulated expression of the SLIT/ROBO pathway in the ovary: possible role during luteolysis in women. Endocrinology 2008; 149: 5024-5034

7 Baird DD, Weinberg CR, McConnaughey DR et al. Rescue of the corpus luteum in human pregnancy. Biol Reprod 2003; 68: 448-456

8 Illingworth DV, Heap RB. A decrease in the metabolic clearance rate of progesterone in the coypu during pregnancy. J Reprod Fertil 1971; 27: 492-494

9 Dejana E. Endothelial cell-cell junctions: happy together. Nat Rev Mol Cell Biol 2004; 5: 261-270

10 Bazzoni G, Dejana E. Endothelial cell-to-cell junctions: molecular organization and role in vascular homeostasis. Physiol Rev 2004; 84: 869-901

11 Walz A, Keck C, Weber $\mathrm{H}$ et al. Effects of luteinizing hormone and human chorionic gonadotropin on corpus luteum cells in a spheroid cell culture system. Mol Reprod Dev 2005; 72: 98-104

12 Delvigne A, Rozenberg S. Review of clinical course and treatment of ovarian hyperstimulation syndrome (OHSS). Hum Reprod Update 2003; 9: 77-96

13 Heger A, Sator M, Pietrowski D. Endometrial receptivity and its predictive value for IVF/ICSI-outcome. Geburtsh Frauenheilk 2012; 72: 710 715

14 Isachenko V, Nawroth F, Rahimi $G$ et al. Vascularised chorioallantoic membrane (CAM) culture system for cryopreserved human ovarian tissue as an alternative to xenotransplantation. Geburtsh Frauenheilk 2011; 71: 862-868

15 Fatemi HM, Popovic-Todorovic B, Papanikolaou E et al. An update of luteal phase support in stimulated IVF cycles. Hum Reprod Update 2007; 13: $581-590$

16 Delvigne A, Rozenberg S. Systematic review of data concerning etiopathology of ovarian hyperstimulation syndrome. Int J Fertil Womens Med 2002; 47: 211-226

17 Dejana E, Orsenigo F, Molendini C et al. Organization and signaling of endothelial cell-to-cell junctions in various regions of the blood and lymphatic vascular trees. Cell Tissue Res 2009; 335: 17-25

18 Dejana E, Tournier-Lasserve E, Weinstein BM. The control of vascular integrity by endothelial cell junctions: molecular basis and pathological implications. Dev Cell 2009; 16: 209-221

19 Cavey M, Rauzi M, Lenne PF et al. A two-tiered mechanism for stabilization and immobilization of E-cadherin. Nature 2008; 453: 751-756

20 Chitaev NA, Troyanovsky SM. Adhesive but not lateral E-cadherin complexes require calcium and catenins for their formation. J Cell Biol 1998; 142: 837-846

21 Nelson WJ, Veshnock PJ. Ankyrin binding to $(\mathrm{Na}++\mathrm{K}+)$ ATPase and implications for the organization of membrane domains in polarized cells. Nature 1987; 328: 533-536

22 Yap AS, Brieher WM, Gumbiner BM. Molecular and functional analysis of cadherin-based adherens junctions. Annu Rev Cell Dev Biol 1997; 13: $119-146$

23 Nitta T, Hata M, Gotoh S et al. Size-selective loosening of the bloodbrain barrier in claudin-5-deficient mice. J Cell Biol 2003; 161: 653660

24 Carmeliet P, Lampugnani MG, Moons L et al. Targeted deficiency or cytosolic truncation of the VE-cadherin gene in mice impairs VEGF-mediated endothelial survival and angiogenesis. Cell 1999; 98: 147-157

25 Groten T, Fraser HM, Duncan WC et al. Cell junctional proteins in the human corpus luteum: changes during the normal cycle and after HCG treatment. Hum Reprod 2006; 21: 3096-3102

26 Langbein L, Grund C, Kuhn C et al. Tight junctions and compositionally related junctional structures in mammalian stratified epithelia and cell cultures derived therefrom. Eur J Cell Biol 2002; 81: 419-435

27 Leach L, Babawale MO, Anderson $M$ et al. Vasculogenesis, angiogenesis and the molecular organisation of endothelial junctions in the early human placenta. J Vasc Res 2002; 39: 246-259

28 You $\mathrm{K}, \mathrm{Xu} X, \mathrm{Fu} \mathrm{J}$ et al. Hyperoxia disrupts pulmonary epithelial barrier in newborn rats via the deterioration of occludin and ZO-1. Respir Res 2012; 13: 36

29 Butt AM, Feng D, Nasrullah I et al. Computational identification of interplay between phosphorylation and O-beta-glycosylation of human occludin as potential mechanism to impair hepatitis $C$ virus entry. Infect Genet Evol 2012; 12: 1235-1245

30 Errede M, Girolamo F, Ferrara G et al. Blood-brain barrier alterations in the cerebral cortex in experimental autoimmune encephalomyelitis. J Neuropathol Exp Neurol 2012; 71: 840-854 
31 Zhu Y, Maric J, Nilsson $M$ et al. Formation and barrier function of tight junctions in human ovarian surface epithelium. Biol Reprod 2004; 71: 53-59

32 Fujibe M, Chiba H, Kojima T et al. Thr203 of claudin-1, a putative phosphorylation site for MAP kinase, is required to promote the barrier function of tight junctions. Exp Cell Res 2004; 295: 36-47

33 Peppi M, Ghabriel MN. Tissue-specific expression of the tight junction proteins claudins and occludin in the rat salivary glands. J Anat 2004; 205: 257-266

34 Wulff C, Dickson SE, Duncan WC et al. Angiogenesis in the human corpus luteum: simulated early pregnancy by HCG treatment is associated with both angiogenesis and vessel stabilization. Hum Reprod 2001; 16 : 2515-2524

35 Wulff C, Wilson H, Largue P et al. Angiogenesis in the human corpus luteum: localization and changes in angiopoietins, tie-2, and vascular endothelial growth factor messenger ribonucleic acid. J Clin Endocrinol Metab 2000; 85: 4302-4309

36 Albert C, Garrido N, Mercader A et al. The role of endothelial cells in the pathogenesis of ovarian hyperstimulation syndrome. Mol Hum Reprod 2002; 8: 409-418

37 Kitajima Y, Endo T, Nagasawa K et al. Hyperstimulation and a gonadotropin-releasing hormone agonist modulate ovarian vascular permeability by altering expression of the tight junction protein claudin- 5 . Endocrinology 2006; 147: 694-699

38 Wulff C, Wiegand SJ, Saunders PT et al. Angiogenesis during follicular development in the primate and its inhibition by treatment with truncated Flt-1-Fc (vascular endothelial growth factor Trap(A40)). Endocrinology 2001; 142: 3244-3254

39 Wulff C, Wilson H, Wiegand SJ et al. Prevention of thecal angiogenesis, antral follicular growth, and ovulation in the primate by treatment with vascular endothelial growth factor Trap R1R2. Endocrinology 2002; 143: 2797-2807

40 Taylor PD, Wilson H, Hillier SG et al. Effects of inhibition of vascular endothelial growth factor at time of selection on follicular angiogenesis, expansion, development and atresia in the marmoset. Mol Hum Reprod 2007; 13: 729-736

41 Rodewald M, Herr D, Fraser HM et al. Regulation of tight junction proteins occludin and claudin 5 in the primate ovary during the ovulatory cycle and after inhibition of vascular endothelial growth factor. Mol Hum Reprod 2007; 13: 781-789

42 Sundfeldt $K$, Piontkewitz Y, Billig $H$ et al. E-cadherin-catenin complex in the rat ovary: cell-specific expression during folliculogenesis and luteal formation. J Reprod Fertil 2000; 118: 375-385

43 Kawagishi R, Tahara $M$, Morishige $K$ et al. Expression of nectin-2 in mouse granulosa cells. Eur J Obstet Gynecol Reprod Biol 2005; 121: $71-76$
44 Alexander JS, Elrod JW. Extracellular matrix, junctional integrity and matrix metalloproteinase interactions in endothelial permeability regulation. J Anat 2002; 200: 561-574

45 Nakhuda GS, Zimmermann RC, Bohlen P et al. Inhibition of the vascular endothelial cell (VE)-specific adhesion molecule VE-cadherin blocks gonadotropin-dependent folliculogenesis and corpus luteum formation and angiogenesis. Endocrinology 2005; 146: 1053-1059

46 Wulff C, Wilson H, Rudge JS et al. Luteal angiogenesis: prevention and intervention by treatment with vascular endothelial growth factor trap(A40). J Clin Endocrinol Metab 2001; 86: 3377-3386

47 Villasante A, Pacheco A, Ruiz A et al. Vascular endothelial cadherin regulates vascular permeability: Implications for ovarian hyperstimulation syndrome. J Clin Endocrinol Metab 2007; 92: 314-321

48 Misrahi M, Beau I, Ghinea N et al. The LH/CG and FSH receptors: different molecular forms and intracellular traffic. Mol Cell Endocrinol 1996; 125: 161-167

49 Rodewald M, Herr D, Duncan WC et al. Molecular mechanisms of ovarian hyperstimulation syndrome: paracrine reduction of endothelial claudin 5 by hCG in vitro is associated with increased endothelial permeability. Hum Reprod 2009; 24: 1191-1199

50 Neulen J, Raczek S, Pogorzelski M et al. Secretion of vascular endothelial growth factor/vascular permeability factor from human luteinized granulosa cells is human chorionic gonadotrophin dependent. Mol Hum Reprod 1998; 4: 203-206

51 Fraser HM, Bell J, Wilson H et al. Localization and quantification of cyclic changes in the expression of endocrine gland vascular endothelial growth factor in the human corpus luteum. J Clin Endocrinol Metab 2005; 90: 427-434

52 Wright TJ, Leach L, Shaw PE et al. Dynamics of vascular endothelial-cadherin and beta-catenin localization by vascular endothelial growth factor-induced angiogenesis in human umbilical vein cells. Exp Cell Res 2002; 280: 159-168

53 Lampugnani MG, Orsenigo F, Gagliani MC et al. Vascular endothelial cadherin controls VEGFR-2 internalization and signaling from intracellular compartments. J Cell Biol 2006; 174: 593-604

54 Kametani Y, Takeichi M. Basal-to-apical cadherin flow at cell junctions. Nat Cell Biol 2007; 9: 92-98

55 Furuse $M$, Tsukita S. Claudins in occluding junctions of humans and flies. Trends Cell Biol 2006; 16: 181-188

56 Van Itallie CM, Anderson JM. Claudins and epithelial paracellular transport. Annu Rev Physiol 2006; 68: 403-429

57 Herr D, Fraser HM, Konrad R et al. Human chorionic gonadotropin controls luteal vascular permeability via vascular endothelial growth factor by down-regulation of a cascade of adhesion proteins. Fertil Steril 2013; 99: 1749-1758 